\title{
Diffusion of Innovation in Service Firms (Hungarian versus Slovakian Business Service Firms) ${ }^{*}$
}

\author{
Csaba Makó, Péter Csizmadia, Miklós Illéssy, Ichiro Iwasaki, Miklós Szanyi**
}

The current global financial and economic crisis has brought into prominence the patterns of economic modernisation of post-socialist countries in the Central and Eastern European (CEE) region. One of the key factors of successful modernisation and sustainability of competitiveness in these economies is the firms' innovative capability. The paper aims to map and assess the various forms of organisational innovations and their drivers based on original company survey data collected in Hungary and Slovakia among firms operating in the Knowledge Intensive Business Services sector in 2008 and 2009.

Die aktuelle globale Finanz- und Wirtschaftskrise hat die Muster der wirtschaftlichen Modernisierung der post-sozialistischen Ländern in Mittel- und Osteuropa (CEE) in den Vordergrund gerückt. Einer der wichtigsten Faktoren für erfolgreiche Modernisierung und Nachhaltigkeit der Wettbewerbsfähigkeit in diesen Ländern ist die Innovationsfähigkeit der Unternehmen. Der Artikel zielt darauf $a b$, die verschiedenen Formern organisationaler Innovationen und ihre Treiber abzubilden und zu bewerten auf der Grundlage einer Befragung von Unternehmen aus dem Bereich der wissensintensiven Unternehmensdienstleistungen in der Slowakei und Ungarn in 2008 und 2009.

Keywords: Modernisation, Knowledge Intensive Business Services (KIBS), Nontechnological innovation, Radical and incremental organisational innovation

\footnotetext{
Manuscript received: 15.12.2010, accepted: 19.06.2012 (4 revisions)

** Csaba Makó, Research Advisor, Hungarian Academy of Sciences, Centre for Social Sciences, Institute of Sociology; Professor, Szent István University Gödöllö. Main research areas: Organisational change (innovation) in learning organisations and their institutional (e.g. labour relations system) context with an international perspective. Corresponding address: mako@socio.mta.hu

Péter Csizmadia, Researcher, Hungarian Academy of Sciences, Centre for Social Sciences, Institute of Sociology. Main research areas: Various aspects of workplace innovation, organisational learning and Knowledge Intensive Business Services. Corresponding address: pcsizmadia@ socio.mta.hu

Miklós Illéssy, Researcher, Hungarian Academy of Sciences, Centre for Social Sciences, Institute of Sociology. Main research areas: Organisational innovation, flexicurity (a confluence of flexibility and security) and Knowledge Intensive Business Services. Corresponding address: illessy@ socio.mta.hu

Ichiro Iwasaki, Professor, Hitotsubashi University Tokyo, Institute of Economics. Main research areas: Transition economies, comparative economic systems, and financial and organisational economics. Corresponding address: iiwasaki@ier.hit-u.ac.jp

Miklós Szanyi, Research Advisor, Hungarian Academy of Sciences, Institute for World Economics; Professor, University of Debrecen, Faculty of Economics and Business Administration. Main research areas: Comparative analysis of market institutions in transition economies as well as corporate performance, and the role of multinational corporate networks in the modernisation process of these countries. Corresponding address: szanyi_miklos@vki.hu
} 


\section{Introduction - "Great Transformation" - Economic structure shift from manufacturing to services}

From the last decades of the $20^{\text {th }}$ century, we have witnessed an unprecedented growth of the service sector at the expense of the manufacturing and agricultural sectors. In this relation, some scholars have labelled this change as a "service sector revolution" (Chesbrough - Shphrer, 2006). In a rather simplistic way, the wealth of nations could be attributed to agriculture two centuries ago, to manufacturing a century ago, and to the service sector nowadays which is producing 70-80\% of GDP in developed economies. In contrast, the share of the service sector in Central and Eastern European Post-Socialist countries ranges from $54 \%$ to $63 \%$ [if you specify other range within $1 \%$ then this parsing is not consistent]

Globalisation of the service sector is rather a new phenomenon driven by the following factors:

(1) The "Great Doubling" in the international labour market: as a result of the participation of China, India and former Soviet bloc countries in the global labour market, today 2.93 billion people are in competition, while only 1.46 billion workers had been active in the global labour market before these historical changes took place. Richard B. Freeman (2005) called this enormous shift in the global labour market the "Great Doubling" that had far reaching impacts on labour, such as increased wage competition not only in low-level blue-collar but also in the case of white-collar jobs.

(2) General use of ICT (due to radical cost reduction) in company practices speeded up the delocalisation (outsourcing/offshoring) of not only the "primary activities" (e.g. production) in the Global Value Chain (GVC) but also the "support activities" in the administrative functions (accountancy, HRM, etc.) (Gospel - Sako, 2009).

(3) In the emerging markets, social and economic players are looking for new development strategies (a new path of economic development) aimed to improve their positions in the Global Value Chain by supplying higher value-added products and services (Makó et al. 2009).

(4) Fast development of "modularisation" or "networking” of firms via various types of organisational and managerial innovations in global corporations is continuing. This process is driven by both cost reduction activities and transformation of firms (e.g. focus on core competencies in both "primary" and "support" activities). ${ }^{12}$

12 According to Sako (2009), in the "modular corporation", the labour process in practically every large corporate department can be delocalised (either by outsourcing or offshoring) and driven both by cost- and knowledge efficiencies, using "new locations with a talent pool" (p. 4.). 
All these trends particularly affect Central European countries such as Slovakia and Hungary. After the collapse of the state socialism system, these countries had to face new challenges of the open markets of the developed countries, in stark contrast to the former protected internal market of the socialist countries (COMECON: Council for Mutual Economic Assistance). The economic modernisation of these countries has largely depended on the ability to satisfy the needs of these highly competitive markets and on the level of annual FDI inflow. Multinational companies are important factors of competitiveness because they create links between GVCs and local companies, and thus provide access to international markets (although the integration of these companies into the local economic environment is often problematic). On the other hand, these companies not only provide capital or leading edge technologies but they are also important forms of organisational innovation. Research on innovation tends to concentrate mainly on the technological aspects of innovation, while organisational innovation has only been given more attention in the last 10-15 years. One of the innovative characteristics of the present research is that it investigates organisational innovation in the Knowledge Intensive Business Services sector of two post-socialist countries.

\section{Developing the typology of organisational innovation: A brief conceptual overview}

Before going into the details concerning the methodology and the results of our research, it is worth dwelling on some important aspects of organisational innovation. Organisational and technological innovations interact with each other - even before the Second World War, Schumpeter (1934) pointed out the interrelatedness of various forms of innovation and went beyond to focus exclusively on the technical side of innovation. In his view, technological and organisational innovations are interrelated, and Lam wrote that Schumpeter "...saw organizational changes, alongside new products and processes, as well as markets as factors of "creative destruction" (Lam, 2005: 115). Schumpeter made a distinction among the following five types of innovation:

1. New products

2. New production methods

3. New markets

4. New sources of supply

5. New forms of organisation

The literature and the empirical research conducted in this field concentrated on product and process innovation, while less attention was paid on the nontechnological forms of innovation (as for example organisational innovation). Among the many attempts to define organisational innovation, we use the one of Armbruster et al. (2006): "the development and implementation of new 
organisational structures and processes to offer customers more flexibility and efficiency" (p.22). Based on this definition, emphasising the importance of changes in both organisational structures and processes, the authors developed a classification of organisational innovation.

The items of their classification (Armbruster et al. 2008) are as follows:

1. Structural organisational innovation, which may modify the divisional structure of organisational functions, hierarchical levels and information flow, or, in general, the organisational architecture of the firm. This type of innovation requires changes in the existing status quo (and related interests) and power relations within the organisation.

2. Procedural organisational innovation, which may change the process and operation routines within the firm, such as improving the flexibility of manpower and the use of knowledge through the implementation of team work, just-in-time (Kan-Ban in Japanese) or quality circles.

3. Intra-organisational innovation which is taking place within an organisation.

4. Inter-organisational aspects of innovation, which refer to new organisational forms and processes that exist beyond the organisational border of the firm.

Throughout of our research, we made attempts to investigate organisational innovation on the basis of the above classification. However, it is important to call attention to the fact that the meaning and operationalisation of organisational innovation is rather problematic because of several factors. One of the most important one is the novel characteristic of organisational innovation "or in other words": how evident?[i don't quite follow here]an organisational innovation must be or can the mere existence of some structures or processes be regarded as innovation? The development of the theoretical debates around this question would exceed the limits of this study. In this research we investigated work related organisational innovations, or to put it more precisely, we focused on the diffusion of innovative work through organisational arrangements.

\section{Research design, sampling and research method}

\subsection{The need to better understand innovation in the KIBS sector in the CEE countries}

Among the Hungarian academic community, there is a scarcity of systematic research on the "non-R\&D type" innovations in general and especially on the social-organisational innovation with regard to the KIBS sector. To overcome this knowledge deficiency, the Research Group of Sociology of Organisation and Work at the Institute of Sociology of the Hungarian Academy of Sciences in Budapest recently initiated a desktop screening of literature on the diffusion of 
organisational innovation and gathered empirical materials learned from its strong involvement in several EU-funded projects. ${ }^{13}$

This paper provides the first analysis of systematically collected company-level data with the objective of better understanding the diffusion and drivers of organisational innovation by comparing the KIBS sectors in Hungary (2008) and Slovakia (2008-2009).

\subsection{Sample of the company survey and sampling method}

The cross-country company survey was designed to collect systematic information on the working practices of business service firms operating in Hungary and Slovakia. ${ }^{14}$ There is no generally accepted definition for "business service" as this category covers rather heterogeneous economic activities. In our study, based on the literature review and with the intention to produce internationally comparable data, the knowledge-intensive professional services offered for other companies are defined as "business services" such as IT services (both software and hardware), administrative and legal services, financial services and R\&D (for more details, see Makó-Illéssy-Csizmadia, 2008). Table 1 contains the activities selected for the purpose of the company surveys in both Hungary and Slovakia.

Table 1: Share of KIBS firms by types of activities (NACE ${ }^{15}$ codes) in Hungary and Slovakia (\%)

\begin{tabular}{|l|c|c|}
\hline Activity & Hungary & Slovakia \\
\hline $\begin{array}{l}\text { Accounting, finance and legal services (NACE } \\
\text { codes: K 66.1, Activities auxiliary to financial } \\
\text { services, except insurance and pension funding; K }\end{array}$ & & \\
$\begin{array}{l}\text { 66.2, Activities auxiliary to insurance and pension } \\
\text { funding; K 64.9, Other financial service activities, } \\
\text { except insurance and pension funding; M 69, Legal } \\
\text { and accounting activities; M 70, Activities of head } \\
\text { offices; management consultancy activities) }\end{array}$ & 20.9 & 22.7 \\
\hline $\begin{array}{l}\text { Human resources management (NACE codes: N 78, } \\
\text { Employment activities; P 85.5, Other education) }\end{array}$ & 19.4 & 20.7 \\
\hline
\end{tabular}

${ }^{13}$ In this respect, it is worth mentioning our involvement in the following EU-funded projects: "Work Organization and Restructuring in the Knowledge Society" (WORKS, Integrating and Strengthening the European Research Area - CIT3/CT/2005-006193, 6 ${ }^{\text {th }}$ FP, 2005/2009, "Measuring the Dynamics of Organization and Work (MEADOW - Priority 7: Citizens and Governance in a Knowledge-based Society 028336, $6^{\text {th }}$ FP, 2007-2010).

14 Regarding the service sector, the following classifications are often used (Salter-Tether, 2006): (1) traditional service (e.g. personal service), (2) system service (e.g. airlines and banking), and (3) Knowledge Intensive Business Services (KIBS). The main focus of our research is on activities classified under KIBS.

15 NACE: "Statistical Classification of Economic Activities" - an international statistical system for the classification and registration of economic activities.

Source: http://ec.europa.eu/competition/mergers/cases/index/nace_all.html 


\begin{tabular}{|l|c|c|}
\hline $\begin{array}{l}\text { Technical engineering, consultancy (NACE codes: M } \\
\text { 71, Architectural and engineering activities; technical } \\
\text { testing and analysis; M 72, Scientific research and } \\
\text { development) }\end{array}$ & 25.2 & 18.5 \\
\hline $\begin{array}{l}\text { Information- and computer-related activities (NACE } \\
\text { codes: J 62, Computer programming, consultancy, } \\
\text { and related activities; J 63, Information service } \\
\text { activities) }\end{array}$ & 21.9 & 21.6 \\
\hline $\begin{array}{l}\text { Advertising, marketing, customer service, other } \\
\text { services (NACE codes: M 73, Advertising, market } \\
\text { research; M 74.3, Translation and interpretation } \\
\text { activities; N 77.3, Renting and leasing of other } \\
\text { machinery, equipment, and tangible goods; N 81.1, } \\
\text { Combined facilities support activities; N81.2.2, Other } \\
\text { building and industrial cleaning activities; N 82.2, } \\
\text { Activities of call centers) }\end{array}$ & 12.6 & 16.5 \\
\hline Total & & 100 \\
\hline
\end{tabular}

In the first quarter of 2008 - according to the National Register of Economic Organizations compiled by the Hungarian Central Statistical Office (HCSO) 4,049 companies with 10 or more employees were registered in the field of business services, while 2,714 were registered in Slovakia (Bajzikova Sajgalikova - Wojcak - Polakova, 2009: 5-6.). In order to design a statistically representative sample of firms, 200 companies were selected from Hungary and 100 companies from Slovakia using a multi-stage stratified sampling method. The basic economic activity of the firms classified by the NACE code was used as the stratification variable. This sampling method ensured equal probability for all companies belonging to the population surveyed to be selected in the sample and reflected the heterogeneity of the organisational population as well. In other words, the sampling structure reflects the composition of the companies operating in various (e.g. "new" and "mature") economic activity branches. The sampling lower treshhold was companies employing at least 10 persons. Firms with 0 to 9 employees were excluded, a based on previous research experience, these firms are hardly available for surveys. Also, because the division of labour within these firms is rather underdeveloped, making it difficult to find and compare the forms of organisational innovation with bigger firms (Valeyre et al., 2009).

\subsection{Structure of the questionnaire and characteristics of data collection}

The field work took place in 2008 in Hungary and the survey was divided into two stages due to the summer holiday season. The Slovakian survey was carried 
out between October 2008 and January 2009 in a rather unfriendly climate for social research in the context of the global financial and economic downturn.

To ensure the quality of data and reliability of data collection, specific steps were taken. In addition to the 200-element sample in Hungary and to the 100element sample in Slovakia, a further 400 companies in Hungary and 200 companies in Slovakia [don't understand this were addressed to reduce the expected refusal rate of the selected population (managers and/or owners).] To guarantee good quality data, in designing the questionnaire, a pilot survey was conducted to test the possible cognitive [interpretive?] contradictions of the draft questions. As a result of the multi-level monitoring of data collection, the final database in the Hungarian business services was restricted to 196 cases and in the Slovakian business services sector to 97 cases, hence ensuring the validity and internal cohesion for the data. To guarantee the statistical representativeness of the survey, the data sets were weighted. The final database is statistically representative of the firm population surveyed, i.e. the 4,094 companies operating with at least 10 employees in the Hungarian and the 2,714 companies operating with at least 10 employees in the Slovakian business service sectors.

The final questionnaire contains 43 questions and was divided into the following four thematic sections:

1. General characteristics of firm. This section contains a description of the architecture of the organisation, ownership, market structure, types of activities and type of technology employed.

2 Composition of management and institutional transfer of business practices. This section includes a report of those firms in which foreign managers are employed, an examination of the share of foreign versus local managers, the recruitment practice of foreign managers and the generic business functions occupied by them. In addition, this section indicates the degree of autonomy of the local subsidiaries in developing their business practices.

3. Diffusion and drivers of organisational innovation. In addition to mapping the differences and/or similarities of forms of organisational innovation, this section contains an examination of the degree of embeddedness of ICT in the business practices of the sectors surveyed. Regarding the forms of organisational innovation, the drivers of innovation are also identified.

4. Characteristics of knowledge development practice of the firm. In this section, the dominant combination of the required skills or competencies is identified. In assessing the training practices of the firms surveyed, we tried to understand not only the roles of the formal training and education in the skill formation of employees but the importance of the so-called on-site (in situ) learning. In addition, particular attention was given to the role of the various external knowledge acquisition sources in skill development. 
In the preliminary analysis of the company survey data, we focus on the factors related to the diffusion and drivers of organisational innovation.

\section{Diffusion and drivers of organisational innovation: the case of the Hungarian and Slovakian KIBS firms}

Our company survey was designed to focus exclusively on intra-organisational innovation and it was not our intention to cover new organisational forms (e.g. network-based firms) that are beyond the scope of the individual firm's organisation. Regarding the various forms of intra-organisational innovation, the diffusion of both structural and procedural organisational innovation was our primary interest. The following forms of structural and procedural organisational innovation were assessed by a representative of the firms surveyed:

a) Structural organisational innovation:

- Project-based work;

- Lean or flat organisation;

- Inter-professional (functional) working groups.

b) Procedural organisational innovation:

- Quality-assurance or continuous improvement process (e.g. ISO, TQM);

- Collecting suggestions from workers;

- Teamwork; ${ }^{16}$

- Benchmarking;

- Job rotation;

- Delegation of quality assurance to workers (decentralisation).

Among the above listed new organisational or managerial practices, "structural organisational innovation" is less often used than its "procedural" version. This is not by chance as structural organisational innovation affects both the "core" components and their relationships within the organisation. These types of changes require significant modification in the existing interest and power relations, and more extensive participation in the collective learning of various social players in the firm. On the other hand, successful procedural innovation can be carried out without a radical shift in the core components and their relationships within an organisation, and requires a rather limited (or "singleloop" type) learning activity from the parties concerned.

\footnotetext{
${ }^{16}$ Both teamwork and job rotation are key components of the lean production and "high-performance work systems", and the use of teams, in particular, has been the subject of many studies concerned with the impact of new managerial practices on enterprise performance and on the quality of work, including worker satisfaction (Kyzlinková, Dokulilová, and Kroupa, 2007).
} 
It is clear from the empirical data collected from the company survey that strong differences characterise the Hungarian and Slovakian KIBS sectors with regard to the diffusion of organisational innovation. For example, such forms of structural (or radical) organisational innovation as project-based work, lean organisation and inter-professional working groups are more widely used in Slovakian than in Hungarian KIBS company practices.

In the case of the diffusion of procedural organisational innovation the contrast diminishes. Teamwork (89.6\% versus $41.7 \%)$, quality management $(33.0 \%$ versus $21.9 \%$ ), and particularly job rotation $(28.9 \%$ versus $9.7 \%$ ) are still much more often used in Slovakian than in Hungarian firms. However, in Hungarian firms, in comparison with the Slovakian practice, quality circles $(23.7 \%$ versus $14.4 \%$ ), benchmarking (37.3\% versus $21.6 \%$ ) and collecting suggestions of employees $(49.7 \%$ versus $41.2 \%$ ) were more prevalent (see Table 2 . for more details).

Table 2: Diffusion of new ('Leading Edge') managerial practices in the KIBS sector

\begin{tabular}{|l|c|c|}
\hline Types of organisational innovation & $\begin{array}{c}\text { Hungary } \\
\mathbf{n = 1 9 6}\end{array}$ & $\begin{array}{c}\text { Slovakia } \\
\mathbf{n = 9 7}\end{array}$ \\
\hline \multicolumn{2}{|l|}{ I. Structural (radical)organisational innovation: } \\
\hline Project-based work & $34.8 \%$ & $69.1 \%$ \\
\hline Flat or lean organisation & $10.7 \%$ & $13.4 \%$ \\
\hline Inter-professional (inter-disciplinary) working groups & $13.4 \%$ & $36.1 \%$ \\
\hline II. Procedural (incremental) organisational innovation: \\
\hline $\begin{array}{l}\text { Quality Assurance and Auditing Systems (e.g. ISO } \\
\text { and TQM) }\end{array}$ & $21.9 \%$ & $33.0 \%$ \\
\hline Collecting suggestions from employees & $49.7 \%$ & $41.2 \%$ \\
\hline Teamwork & $41.7 \%$ & $89.6 \%$ \\
\hline Benchmarking & $37.3 \%$ & $21.6 \%$ \\
\hline $\begin{array}{l}\text { Quality control carried out by rank-and-file } \\
\text { employees }\end{array}$ & $23.7 \%$ & $14.4 \%$ \\
\hline Job rotation & $9.7 \%$ & $28.9 \%$ \\
\hline
\end{tabular}

Note: Attempts to classify different types of organisational innovation based on the approach of Armbruster et al. (2008: 646-647).

In mapping the diffusion of organisational innovation, our respondents were also asked to assess the drivers of implementation of new organisational concepts 
and practices. In both countries, the most important driver is the improvement of the efficiency of daily operations. This factor is followed by the motives of renewing the existing knowledge base, adapting to the environmental changes, strengthening cooperation within the organisation, improving quality and customer service and increasing the size of the firm. Surprisingly enough, the outsourcing or delocalising business services received the lowest assessment among the driver of organisational changes in both countries. It is noteworthy to mention that such drivers of organisational changes as the renewal of product and services, the renewal of existing knowledge, increasing the size of the firm, and especially outsourcing business functions are less significant in Slovakian company practices than in Hungarian ones (see Table 3. for more details).

Table 3: Driving forces behind important organisational changes in the KIBS sector*

\begin{tabular}{|l|c|c|}
\hline Drivers of organisational changes & $\begin{array}{c}\text { Hungary } \\
\mathbf{n = 1 9 6}\end{array}$ & $\begin{array}{c}\text { Slovakia } \\
\mathbf{n = 9 7}\end{array}$ \\
\hline Improving daily efficiency of work & $73.9 \%$ & $67.0 \%$ \\
\hline $\begin{array}{l}\text { Strengthening cooperation within the } \\
\text { firm }\end{array}$ & $61.5 \%$ & $53.6 \%$ \\
\hline Adapting to environmental changes & $62.8 \%$ & $62.9 \%$ \\
\hline Renewal of product and services & $54.3 \%$ & $36.0 \%$ \\
\hline Renewal of the existing knowledge base & $63.5 \%$ & $33.0 \%$ \\
\hline Outsourcing business functions & $36.8 \%$ & $16.5 \%$ \\
\hline Improving quality and customer service & $65.9 \%$ & $44.4 \%$ \\
\hline Increasing size of the firm & $42.5 \%$ & $37.2 \%$ \\
\hline
\end{tabular}

Note: Drivers of organisational changes were assessed by managers on a 5 point scale, where $1=$ the least important and $5=$ the most important factor.

*: Significant at the $5 \%$ level.

Finally, regarding the drivers of organisational innovation Table 4 indicates the main reasons for the lack of organisational innovation. Particularly in the case of Hungary, a significant share of the firms (43\% and $12.4 \%$ in Slovakia) carried out organisational changes before the reference period (2005-2007) and therefore no further efforts were deemed necessary to modernise organisational practice. In addition, one-third of the Hungarian but only one-tenth of the Slovakian firms' representativeslindicated that even during the reference period (2005-2007) there was no need for organisational innovation. 
Table 4: Reasons for the absence of organisational innovation in the KIBS sector*

\begin{tabular}{|l|c|c|}
\hline $\begin{array}{l}\text { Factors responsible for the lack of } \\
\text { organisational innovation }\end{array}$ & $\begin{array}{c}\text { Hungary } \\
\mathbf{N = 1 9 6}\end{array}$ & $\begin{array}{c}\text { Slovakia } \\
\mathbf{n = 9 7}\end{array}$ \\
\hline $\begin{array}{l}\text { No need for organisational innovation from } \\
\text { 2005 to 2007 }\end{array}$ & $33.0 \%$ & $10.3 \%$ \\
\hline $\begin{array}{l}\text { Implementation of organisational innovation } \\
\text { before 2005-2007; since then, no need for } \\
\text { further changes }\end{array}$ & $43.0 \%$ & $12.4 \%$ \\
\hline Lack of financial resources & $6.9 \%$ & $6.2 \%$ \\
\hline Skill shortage & $6.9 \%$ & $6.2 \%$ \\
\hline $\begin{array}{l}\text { Resistance of employees and managers to } \\
\text { change }\end{array}$ & $5.4 \%$ & $7.3 \%$ \\
\hline
\end{tabular}

Note: Employers interviewed assessed these factors on a 5 point scale, where $1=$ least important and $5=$ most important with regard to the absence of organisational innovation.

These relatively substantial differences between the two countries regarding the reasons for the lack of innovation may be attributed to the different state? of economic development. Although we do not have enough empirical evidence on the different cycles of the Slovakian and Hungarian economic development, one may argue that the innovation activity of the firms depends on the country's economic climate in a given period of time. The relatively high share of Hungarian firms that introduced organisational innovation before 2005 (43\%) compared to their Slovakian counterparts (12.4\%) may allow us to conclude that one of the reasons for Slovakian firms being more active innovators is the different economic context of the two countries. At the same time, the economic downturn in Hungary - which started already before the global economic crisis did not favour these firms in their innovation activities either.

Finally, it is worth noting that in the literature related to technological and organisational changes, the resistance of employees/managers and skill shortages are frequently reported as constraints to these changes. However, in this survey, such factors were only reported by a small minority of respondents and only in conjunction with the lack of financial resources. 


\section{References}

Armbruster, H., E. Kirner, G. Lay, M. Szwejczewski, B. Coriat, C. Leguehennec, R. Evangelista, M. Pianta, C. Cozza, J. Belak, J. Belak and M. Duh (2006) Patterns of Organisational Change in European Industry (PORCH). Karlsruhe, Frauenhofer, Institute Systems and Innovation Research: 1-66.

Armbruster, H. - Bikfalvi, A. - Kinkel, S. - Lay, G. (2008) Organizational Innovation: The Challenge of Measuring Non-Technical Innovation in Large-Scale Surveys. Science Direct - Technoinnovation, No. 28

Chesbrough, H. - Shphrer, J. (2006) Service Science: A Research Manifesto, Haas School of Business - University California Berkeley - IBM Research Centre, 18th March.

European Innovation Scoreboard (2009) Comparative Analysis of Innovation Performance, Brussels: EU DG Enterprise and Industry

Finegold, D. - Soskice, D. (1988) The Failure of Training in Britain: Analysis and Prescription, Oxford Review of Economic Policy, Autumn, pp. 21-51.

Freeman, R. B. (2005) The Great Doubling: labor in the new global economy, Georgia State University, Lecture in labor studies.

Gospel, H. - Sako, M. (2009) The Unbundling of Corporate Functions: The Evolution of Shared Services and Outsourcing in Human Resource Management, King's College London - Said Business School - Oxford University, p. 36. (Draft to be submitted to Industrial and Corporate Change)

Lam, A. (2005) Organizational Innovation, In: Fagerberg, J. - Mowery, D. C. - Nelson, R. R. (eds.) The Oxford Handbook of Innovation, Oxford: Oxford University Press, pp. 115147.

Makó, Cs. - Csizmadia, P. - Illéssy, M. - Kirov, V. - Galev, T. (2009) Work in Transformation Economies' (The Case of the New Member States), Leuven: Catholique University Leuvan - Institute for Advanced Labour Studies (HIVA)

Makó, Cs. - Csizmadia, P. - Illéssy, M. (2008) Innovációk az üzleti szolgáltatási szektorban: az új szervezeti értékek és tudásfelhasználási minták, (Innovation in the Business Service Sector - New Patterns of Knowledge Use and Organizational Value) Research Report Prepared for the IBM Hungary Kft. Budapest: Munkatudományi Tanszék Debreceni Egyetem Közgazdasági Kar - MTA Szociológiai Kutatóintézet

Mintzberg, H. (1979) The Structuring of Organisations. Englewood Cliffs, NJ, Prentice Hall.

Nielsen, P. - Lundvall, B. - A. (2007) Innovation, Learning Organizations and Employment Relations, In: Makó, Cs. - Moerel, H. - Illéssy, M. - Csizmadia, P. (eds.) Working It Out? The Labour Process and Employment Relations in the New Economy, Budapest: Akadémiai Kiadó, p. 74.

Salter, A. - Tether, B. S. (2006) Innovation in Services (Through the Looking Glass of Innovation Studies), Advanced Institute of Management (AIM), Research's Grand Challenges on Service Science.

Schumpeter, J. (1934) The Theory of Economic Development, Cambridge, Mass.: Harvard University Press 
Toivonen, M. (2006) Future Prospects of Knowledge-Intensive Business Services (KIBS) and Implications to Regional Economies, ICFAI Journal of Knowledge Management, Vol. 4, No. 3, pp. 18-36.

Valeyre, A. - Lorenz, E. - Cartron, D. - Csizmadia, P. - Gollac, M. - Illéssy, M. - Makó, Cs. (2009) Working conditions in the European Union: Work organization, Luxemburg: Office for Official Publications of the European Communities 